\title{
Article \\ Insight on the Structure-to-Activity of Carbosilane Metallodendrimers in the Fight against Staphylococcus aureus Biofilms
}

\author{
Celia Llamazares ${ }^{1}$, Natalia Sanz del Olmo ${ }^{2}$, Juan Soliveri ${ }^{1}$, F. Javier de la Mata ${ }^{2,3,4}\left(\mathbb{D}\right.$, José Luis Copa-Patiño ${ }^{1}$ (D) \\ and Sandra García-Gallego 2,3,4,* \\ 1 University of Alcala, Department of Biomedicine and Biotechnology, 28805 Madrid, Spain; \\ celia.llamazares@edu.uah.es (C.L.); juan.soliveri@uah.es (J.S.); josel.copa@uah.es (J.L.C.-P.) \\ 2 University of Alcala, Research Institute in Chemistry "Andrés M. del Río" (IQAR) and Faculty of Science, \\ Department of Organic and Inorganic Chemistry, 28805 Madrid, Spain; natalia.sanzo@edu.uah.es (N.S.d.O.); \\ javier.delamata@uah.es (F.J.d.1.M.) \\ 3 Networking Research Center on Bioengineering, Biomaterials and Nanomedicine (CIBER-BBN), \\ 28029 Madrid, Spain \\ 4 University of Alcala, Institute Ramón y Cajal for Health Research (IRYCIS), 28034 Madrid, Spain \\ * Correspondence: sandra.garciagallego@uah.es
}

check for updates

Citation: Llamazares, C.; Sanz del Olmo, N.; Soliveri, J.; de la Mata, F.J.; Copa-Patiño, J.L.; García-Gallego, S. Insight on the Structure-to-Activity of Carbosilane Metallodendrimers in the Fight against Staphylococcus aureus Biofilms. Antibiotics 2021, 10, 589. https://doi.org/10.3390/ antibiotics 10050589

Academic Editor: Hao Song

Received: 21 April 2021

Accepted: 12 May 2021

Published: 17 May 2021

Publisher's Note: MDPI stays neutral with regard to jurisdictional claims in published maps and institutional affiliations.

\begin{abstract}
Biofilm formation is a critical health concern, involved in most human bacterial infections. Combatting this mechanism, which increases resistance to traditional antibiotics and host immune defences, requires novel therapeutic approaches. The remarkable biocide activity and the monodispersity of carbosilane metallodendrimers make them excellent platforms to evaluate the impact of different structural parameters on the biological activity. In this work, we explore the influence of iminopyridine ring substituents on the antibacterial activity against planktonic and biofilm Staphylococcus aureus. New families of first-generation $\mathrm{Ru}(\mathrm{II})$ and $\mathrm{Cu}$ (II) metallodendrimers were synthesised and analysed, in comparison to the non-substituted counterparts. The results showed that the presence of methyl or methoxy groups in meta position to the imine bond decreased the overall positive charge on the metal ion and, subsequently, the activity against planktonic bacteria. However, it seemed a relevant parameter to consider for the prevention of biofilm formation, if they contribute to increasing the overall lipophilicity. An optimum balance of the charge and lipophilicity of the metallodrug, accomplished through structural design, will provide effective biocide agents against bacteria biofilms.
\end{abstract}

Keywords: dendrimer; metallodendrimer; metal; copper; ruthenium; antibacterial; biofilm; Staphylococcus aureus

\section{Introduction}

Staphylococcus aureus are Gram-positive bacteria which represent a serious health issue. S. aureus belongs to the Staphylococcaceae family and appears in coconut shape with 0.5 to 1.5 microns diameter, arranged in pairs, clusters or chains [1]. The widespread dissemination of this microorganism, together with its virulence and antibiotic resistance, produces an important impact on morbidity at community and intra-hospital levels [2]. This partly arises from its ability to adhere to the surface of permanent medical devices and develop biofilms [3]. Biofilms represent an evolved system that enables bacteria to survive in hostile environments, forming permanent colonies prone to dissociate and form new colonies [4-6]. Biofilms are up to 1000 times more resilient to the treatment with conventional antibiotics, compared to planktonic bacterial growth [7]. All these circumstances increase the survival capacity of $S$. aureus and the situation is aggravated by the multiple antibiotic resistance developed by the pathogen, hindering the treatment of diseases caused by these bacteria [8]. 
Nanotechnology provides innovative solutions in the fight against infectious diseases, including biofilm-forming bacteria [9]. Metal nanoparticles, carbon-based nanomaterials, liposomes, polymeric nanoparticles and dendrimers with antimicrobial activity have been reported in the literature. In particular, dendrimers and dendritic materials are sophisticated tools in the treatment, prevention and diagnosis of highly prevalent infectious diseases $[10,11]$. They offer advantages such as the highly branched globular conformation, the monodispersity and the multivalent decoration on their surface. Indeed, most antimicrobial dendrimers - peptidic, glycodendrimers, quaternary ammonium decoratedexploit the multivalence to efficiently bind to the negatively charged bacteria membrane or the membrane components and subsequently causing cell membrane disruption.

The antimicrobial action can be further improved by the presence of metal ions in the nanoparticle, which can damage microbial cells through membrane degradation, protein dysfunction and oxidative stress [12]. So far, a very few examples of antimicrobial metallodendrimers have been reported in the literature [13]. Our group recently confirmed the outstanding antibacterial activity of iminopyridine carbosilane dendrimers bearing $\mathrm{Ru}$ (II) and $\mathrm{Cu}$ (II) complexes [14]. The presence of the hydrophobic, stable and flexible carbosilane scaffold enhances the interaction with biological membranes and improves the overall biological activity [15]. Parameters such as the dendrimer generation, the nature of the metal ion or the ligands on the metal enabled a fine-tuning of the bacteriostatic and bactericide activity. An additional parameter-the substituents on the iminopyridine ringhas recently proved to be key for the biological activity of these metallodendrimers [16]. Electron-donating substituents, such as methyl and methoxy, in para- position to the pyridine nitrogen and in meta- position to the imine group, significantly increased the antitumor properties towards myeloid cancer cells. Surprisingly, this behaviour was only observed if the inductive and resonant properties of the substituent were paired with the right metal counterion. The methyl/chloride and methoxy/nitrate pairs unveiled potent antitumor activities of $\mathrm{Cu}$ (II) metallodendrimers, but through two different mechanisms of action. This exemplifies the importance of adequately designing the dendritic scaffold to maximise the biological activity.

Encouraged by this revelation, we herein analyse the influence of this parameter-the substituents on the iminopyridine ring - with the final aim of improving the antimicrobial activity against biofilm-forming bacteria. We present a new family of $\mathrm{Ru}$ (II) and $\mathrm{Cu}$ (II) metallodendrimers bearing $\mathrm{R}$ substituents in meta- position to the imine bond, as an alternative to traditional antibiotics. Bacteriostatic and bactericide activity against $S$. aureus is tested, in both planktonic and biofilm forms, and compared to the non-substituted counterparts. A useful structure-to-activity insight is provided for the designing of effective antibacterial agents.

\section{Results}

A library of compounds was selected to evaluate the impact of the ring substituent as well as the nature of the metal and the ligands. Considering the promising results obtained in our former studies, only first generation metallodendrimers were targeted in this work. The selected families comprised ruthenium (II) metallodendrimers with cymene ligand $\mathrm{G}_{1}-\left[\left[\mathrm{NCPh}(o-\mathrm{N})(m-\mathrm{R}) \mathrm{Ru}\left(\eta^{6}-p \text {-cymene }\right) \mathrm{Cl}\right] \mathrm{Cl}\right]_{4}(\mathbf{1}-\mathbf{R})$, and copper (II) metallodendrimers with nitrate $\mathrm{G}_{1}-\left[\mathrm{NCPh}(o-\mathrm{N})(m-\mathrm{R}) \mathrm{Cu}\left(\mathrm{ONO}_{2}\right)_{2} \cdot \mathrm{H}_{2} \mathrm{O}\right]_{4}(2-\mathrm{R})$ and chloride $\mathrm{G}_{1}-[\mathrm{NCPh}(o-\mathrm{N})(m-$ R) $\left.\mathrm{CuCl}_{2} \cdot \mathrm{H}_{2} \mathrm{O}\right]_{4}$ (3-R) ligands (Figure 1). The iminopyridine substituent $\mathrm{R}$ was $\mathrm{H}, \mathrm{Me}$ and OMe. The $\mathrm{Ru}(\mathrm{II})$ metallodendrimer with $\mathrm{R}=\mathrm{H}$ and all the $\mathrm{Cu}$ (II) metallodendrimers were synthesised according to the published protocols $[16,17]$. 


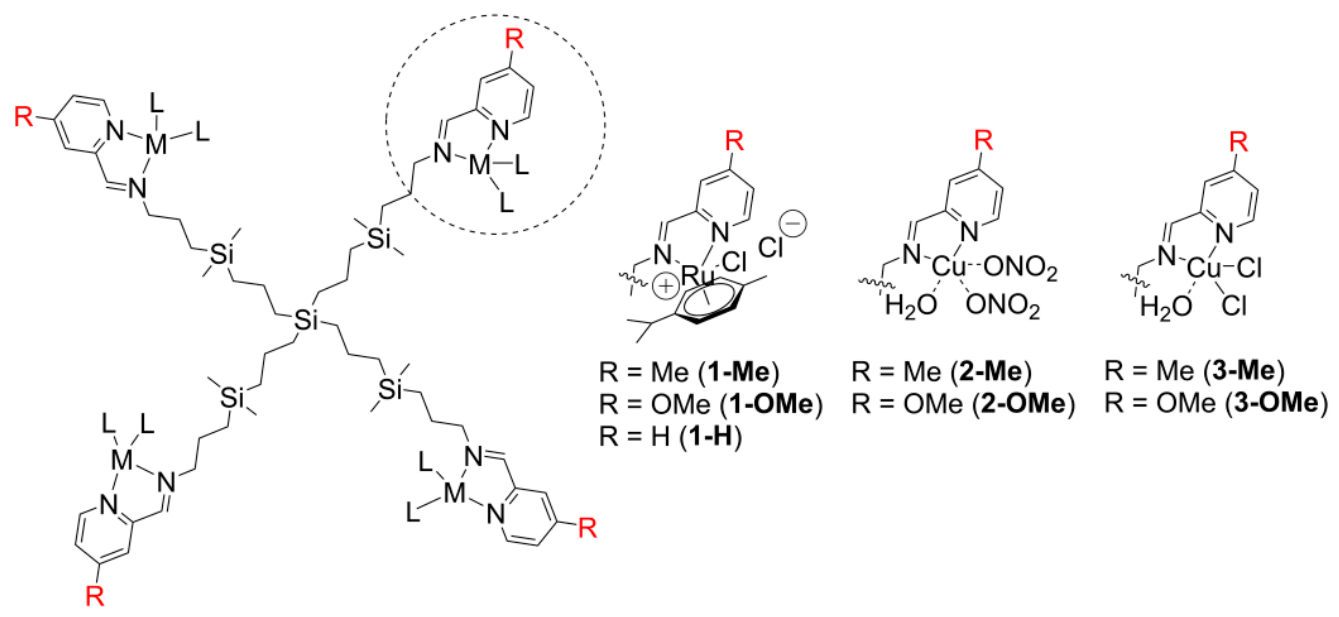

Figure 1. Chemical representation of the $\mathrm{Ru}(\mathrm{II})$ and $\mathrm{Cu}(\mathrm{II})$ carbosilane metallodendrimers, bearing R-substituents in meta position to the imine moiety.

\subsection{Synthesis and Characterisation of Ru(II) Metallodendrimers with R-Substituted Iminopyridine Rings}

The synthesis of the new $\mathrm{Ru}(\mathrm{II})$ metallodendrimers followed a parallel route to the one leading to $\mathrm{G}_{1}-\left[\left[\mathrm{NCPh}(o-\mathrm{N})(m-\mathrm{H}) \mathrm{Ru}\left(\eta^{6}-p \text {-cymene }\right) \mathrm{Cl}\right] \mathrm{Cl}\right]_{4}(\mathbf{1}-\mathbf{H})$ [17]. In this case, the dendrimers $\mathrm{G}_{1}-\left[\mathrm{NCPh}(o-\mathrm{N})\left(m-\mathrm{CH}_{3}\right)\right]_{4}(\mathrm{I})$ and $\mathrm{G}_{1}-\left[\mathrm{NCPh}(o-\mathrm{N})\left(m-\mathrm{OCH}_{3}\right)\right]_{4}(\mathrm{II})$ [16] were used as precursors, Scheme 1 . The addition of $\left[\mathrm{Ru}\left(\eta^{6}-p \text {-cymene }\right) \mathrm{Cl}_{2}\right]_{2}$ to the dendrimer solution in ethanol in a ratio 1:1 branch:[Ru] led to the formation of the metallodendrimers $\mathrm{G}_{1}$ $\left[\left[\mathrm{NCPh}(o-\mathrm{N})(m-\mathrm{Me}) \mathrm{Ru}\left(\eta^{6}-p \text {-cymene }\right) \mathrm{Cl}\right] \mathrm{Cl}\right]_{4}(\mathbf{1}-\mathrm{Me})$ and $\mathrm{G}_{1}-\left[\left[\mathrm{NCPh}(o-\mathrm{N})(m-\mathrm{OMe}) \mathrm{Ru}\left(\eta^{6}-\right.\right.\right.$ $p$-cymene $\mathrm{Cl}] \mathrm{Cl}]_{4}(\mathbf{1 - O M e})$, respectively. Both metallodendrimers were characterised by ${ }^{1} \mathrm{H}-\mathrm{NMR},{ }^{13} \mathrm{C}-\mathrm{NMR}$ and elemental analysis. The analytical and spectroscopic data (see Experimental Section and Supplementary Material) confirmed the presence of the structures shown in Figure 1.

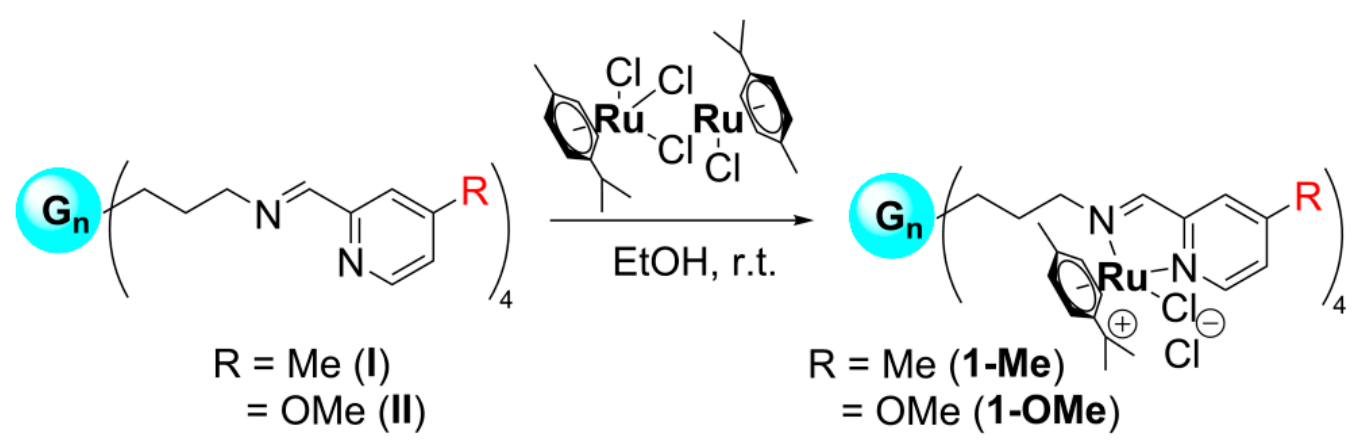

Scheme 1. Synthesis of new $\mathrm{Ru}(\mathrm{II})$ metallodendrimers bearing R-substituted iminopyridine rings.

The metal coordination to the iminopyridine groups in the precursors I and II was confirmed by the shifting of the signals to higher frequency in ${ }^{1} \mathrm{H}-\mathrm{NMR}$ and ${ }^{13} \mathrm{C}-\mathrm{NMR}$ spectra. Table 1 summarises the most significant shifts in ${ }^{1} \mathrm{H}-\mathrm{NMR}$ and further details can be found in the Supporting Information. The pyridine signals, which appear at 7.1-8.5 ppm for the methyl-precursor I and at 6.8-8.4 ppm for the methoxy-precursor II, are significantly shifted, up to +0.8 ppm for the proton in meta- position. The imine group $-\mathrm{CH}=\mathrm{N}$ shifts +0.30 ppm and the adjacent methylene groups undergo a significant change: besides the important shift, two sets of signals appear for each methylene group. 
Table 1. ${ }^{1} \mathrm{H}-\mathrm{NMR}$ shifts for selected signals in the new $\mathrm{Ru}(\mathrm{II})$ metallodendrimers and increase compared to the precursor dendrimers I and II [16].

\begin{tabular}{|c|c|c|c|c|c|c|}
\hline \multirow[b]{2}{*}{ Dendritic Fragment } & \multicolumn{6}{|c|}{$\delta(\mathrm{ppm})$} \\
\hline & Signal & 1-Me & $\Delta$ & Signal & 1-OMe & $\Delta$ \\
\hline \multirow{4}{*}{$-\mathrm{Si}\left(\mathrm{CH}_{2}\right)_{3} \mathrm{~N}=\mathrm{CH}-$} & $-\mathrm{SiCH}_{2}$ & 0.64 & 0.12 & $-\mathrm{SiCH}_{2}$ & 0.62 & 0.10 \\
\hline & $-\mathrm{CH}_{2-}$ & $1.94 / 2.04$ & $0.26 / 0.36$ & $-\mathrm{CH}_{2-}^{-}$ & $1.93 / 2.04$ & $0.26 / 0.37$ \\
\hline & $-\mathrm{CH}_{2} \mathrm{~N}$ & $4.24 / 4.68$ & $0.62 / 1.06$ & $-\mathrm{CH}_{2} \mathrm{~N}$ & $4.24 / 4.67$ & $0.63 / 1.06$ \\
\hline & $\mathrm{N}=\mathrm{C} H$ & 8.62 & 0.30 & $\mathrm{~N}=\mathrm{C} H$ & 8.59 & 0.30 \\
\hline \multirow{4}{*}{ R-Py } & $O^{-}$ & 8.00 & 0.21 & $O^{-}$ & 7.75 & 0.28 \\
\hline & $m-$ & 9.30 & 0.82 & $m-$ & 9.22 & 0.83 \\
\hline & $p-$ & 7.64 & 0.54 & $p-$ & 7.34 & 0.54 \\
\hline & $\mathrm{Me}$ & 2.61 & 0.25 & $\mathrm{OMe}$ & 4.05 & 0.20 \\
\hline
\end{tabular}

\subsection{Surface Charge of Ru(II) Metallodendrimers}

In order to characterise the surface charge of the $\mathrm{Ru}(\mathrm{II})$ metallodendrimers, conductivity and zeta potential measurements were performed. For an accurate comparison, samples were tested at the same concentration. The results from both techniques concluded that the selected metallodendrimers exhibited cationic properties (Table 2). The highest conductivity $(160.2 \mu \mathrm{S} / \mathrm{cm})$ was obtained with $\mathbf{1 - H}$, followed by the substituted counterparts 1-OMe and 1-Me. The high Z-potential values in the range 50.2-61.2 $\mathrm{mV}$ also confirmed the overall cationic charge in the molecule. Compared to the analogous $\mathrm{Ru}$ (II) metallodendrimer with Cp/PTA ligands $4-\mathbf{H}$, the compounds bearing cymene ligands duplicated the Z-potential values.

Table 2. Bacteriostatic and bactericide effect of first-generation carbosilane $\mathrm{Ru}(\mathrm{II})$ metallodendrimers in $\mathrm{S}$. aureus planktonic cells (MIC, MBC) and biofilm-forming cells (MBIC, MIC, MBC-B).

\begin{tabular}{|c|c|c|c|c|c|c|c|c|}
\hline \multirow[b]{2}{*}{ Metallodendrimer } & \multirow[b]{2}{*}{ Ligand/Counterion } & \multirow{2}{*}{$\begin{array}{l}\text { Conductivity } \\
{[\mu S / \mathrm{cm}]}\end{array}$} & \multirow{2}{*}{$\begin{array}{c}\text { Zeta Potential } \\
{[\mathrm{mV}]}\end{array}$} & \multicolumn{2}{|c|}{ Planktonic } & \multicolumn{3}{|c|}{ Biofilm } \\
\hline & & & & $\begin{array}{c}\mathrm{MIC} \\
{[\mathrm{mg} / \mathrm{L}]}\end{array}$ & $\begin{array}{c}\mathrm{MBC} \\
{[\mathrm{mg} / \mathrm{L}]}\end{array}$ & $\begin{array}{l}\mathrm{MBIC} \\
{[\mathrm{mg} / \mathrm{L}]}\end{array}$ & $\begin{array}{c}\mathrm{MIC} \\
{[\mathrm{mg} / \mathrm{L}]}\end{array}$ & $\begin{array}{l}\text { MBC-B } \\
{[\mathrm{mg} / \mathrm{L}]}\end{array}$ \\
\hline 1-H & Cym/Cl & 160.2 & $61.2 \pm 0.7$ & 16 & 32 & 32 & 32 & 64 \\
\hline 1-Me & $\mathrm{Cym} / \mathrm{Cl}$ & 137.5 & $59.5 \pm 0.9$ & 64 & 128 & 16 & 64 & 64 \\
\hline 1-OMe & Cym/Cl & 140.1 & $50.2 \pm 0.7$ & 32 & 128 & 32 & 64 & 128 \\
\hline $4-H^{a}$ & Cp-PTA/Cl & $\mathrm{b}$ & $25.6 \pm 4.7$ & 4 & 4 & 32 & 32 & 128 \\
\hline
\end{tabular}

a Previously published results [14]. ${ }^{\mathrm{b}}$ Not reported. Abbreviations: Cym, cymene; Cp, cyclopentadienyl; PTA, 1,3,5-Triaza-7phosphaadamantane.

\subsection{Antibacterial Activity of Ru(II) Carbosilane Metallodendrimers Against Planktonic and Biofilms S. aureus}

In the previous work, $\mathrm{Ru}$ (II) carbosilane metallodendrimes had shown a potent antibacterial activity in planktonic cells, which even surpassed the activity of $\mathrm{Cu}(\mathrm{II})$ analogues. However, the bacteriostatic and bactericide effect decreased when S. aureus are prompt to form biofilm. Herein, the antibacterial behaviour of $\mathrm{Ru}(\mathrm{II})$ metallodendrimers 1-R was evaluated towards Staphylococcus aureus as a model of Gram-positive bacteria. Two different experiments were performed: First, the activity towards planktonic $S$. aureus. Second, the activity to prevent the formation of S. aureus biofilm. Table 2 summarises the obtained values for the minimum inhibitory concentration (MIC) and the minimum bactericidal concentration (MBC) for each $\mathrm{Ru}(\mathrm{II})$ complex, as well as minimum biofilm formation inhibitory concentration (MBIC) and the minimum bactericidal concentration for biofilms formation (MBC-B).

The data shown in Table 2 indicate that $\mathrm{Ru}(\mathrm{II})$ metallodendrimers bearing cymene ligands are moderate antibacterial agents towards $S$. aureus. These metallodendrimers, with four metal atoms in their periphery, displayed planktonic MIC values in the range 16$64 \mathrm{mg} / \mathrm{L}$ for S. aureus. The highest activity is found for 1-H, followed by 1-OMe and 1-Me. Regarding the nature of the ligands in the $\mathrm{Ru}(\mathrm{II})$ complex, the presence of cymene clearly 
reduced the efficacy of the metallodrug, compared to the $\mathrm{Cp} / \mathrm{PTA}$ analogue which had an excellent MIC value of $4 \mathrm{mg} / \mathrm{L}$. Nevertheless, the impact of the ring substituent and the ligand was observed in S. aureus biofilms. In this assay, similar values were obtained for the four $\mathrm{Ru}$ (II) metallodendrimers tested. The moderate values of $4-\mathrm{H}(\mathrm{MBIC}=32 \mathrm{mg} / \mathrm{L}$ and $\mathrm{MBC}-\mathrm{B}=128 \mathrm{mg} / \mathrm{L}$ ) were even slightly improved, as observed in 1-Me $(\mathrm{MBIC}=16 \mathrm{mg} / \mathrm{L}$ and $\mathrm{MBC}-\mathrm{B}=64 \mathrm{mg} / \mathrm{L}$ ).

\subsection{Antibacterial Activity of Cu(II) Carbosilane Metallodendrimers Against Planktonic and Biofilms S. aureus}

While $\mathrm{Ru}(\mathrm{II})$ metallodendrimers are moderate candidates, the $\mathrm{Cu}(\mathrm{II})$ counterparts have shown potent bacteriostatic and bactericide activity in both planktonic and biofilm $S$. aureus. In order to explore the impact of the substituents on the iminopyridine ring, we performed a similar study to that described for $\mathrm{Ru}(\mathrm{II})$ metallodendrimers. The results are summarised in Table 3 and Figure 2.

Table 3. Bacteriostatic and bactericide effect of first-generation carbosilane $\mathrm{Cu}(\mathrm{II})$ metallodendrimers in $\mathrm{S}$. aureus planktonic cells (MIC, MBC) and biofilm-forming cells (MBIC, MIC, MBC-B).

\begin{tabular}{|c|c|c|c|c|c|c|}
\hline \multirow[b]{2}{*}{ Metallodendrimer } & \multirow[b]{2}{*}{ Counterion } & \multicolumn{2}{|c|}{ Planktonic } & \multicolumn{3}{|c|}{ Biofilm } \\
\hline & & $\begin{array}{c}\mathrm{MIC} \\
{[\mathrm{mg} / \mathrm{L}]}\end{array}$ & $\begin{array}{c}\mathrm{MBC} \\
{[\mathrm{mg} / \mathrm{L}]}\end{array}$ & $\begin{array}{l}\text { MBIC } \\
{[\mathrm{mg} / \mathrm{L}]}\end{array}$ & $\begin{array}{c}\text { MIC } \\
{[\mathrm{mg} / \mathrm{L}]}\end{array}$ & $\begin{array}{c}\text { MBC-B } \\
{[\mathrm{mg} / \mathrm{L}]}\end{array}$ \\
\hline $2-\mathrm{H}^{\mathrm{a}}$ & $\mathrm{ONO}_{2}$ & 4 & 8 & 4 & 8 & 8 \\
\hline 2-Me & $\mathrm{ONO}_{2}$ & 64 & 128 & 32 & 64 & 128 \\
\hline 2-OMe & $\mathrm{ONO}_{2}$ & 16 & 64 & 32 & 64 & 64 \\
\hline $3-\mathbf{H}^{\mathrm{a}}$ & $\mathrm{Cl}$ & 2 & 4 & 8 & 8 & 16 \\
\hline 3-Me & $\mathrm{Cl}$ & 16 & 64 & 32 & 64 & 128 \\
\hline 3-OMe & $\mathrm{Cl}$ & 8 & 16 & 8 & 16 & 32 \\
\hline
\end{tabular}

a Previously published results [14].

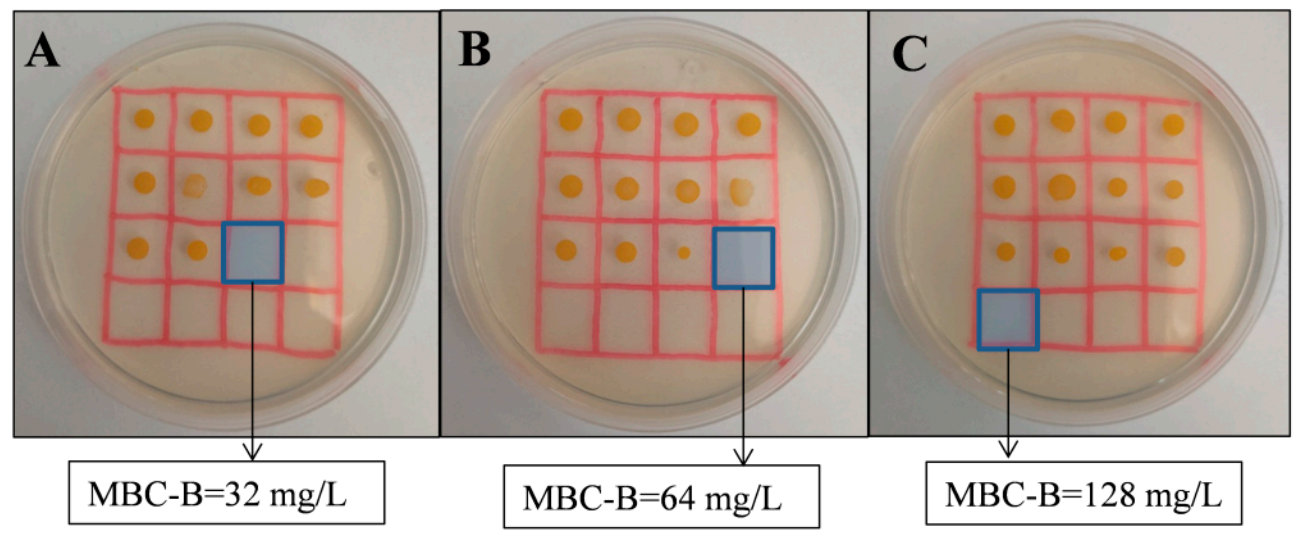

Figure 2. Effect of R-substituted metallodendrimers in preventing the formation of S. aureus biofilms. (A) Compound 3-OMe, with $\mathrm{Cu}$ (II) chloride complex; (B) compounds 2-OMe and 1-Me, with $\mathrm{Cu}$ (II) nitrate and $\mathrm{Ru}$ (II) cymene complexes, respectively; and (C) compounds 2-Me, 3-Me and 1-OMe, with $\mathrm{Cu}$ (II) nitrate, $\mathrm{Cu}$ (II) chloride and $\mathrm{Ru}$ (II) cymene complexes, respectively. The minimum bactericidal concentration for biofilms (MBC-B) represents the minimal concentration of the metallodendrimer that can kill the microorganism in the conditions used to produce a biofilm.

In planktonic cells, non-substituted metallodendrimers $\mathbf{2}-\mathbf{H}$ and $\mathbf{3}-\mathbf{H}$ had previously shown outstanding activity ( $\mathrm{MIC}=4$ and $2 \mathrm{mg} / \mathrm{L}$, respectively). As data on Table 3 indicate, the presence of ring substituents increased the MIC values in the trend $\mathrm{H}<\mathrm{OMe}<\mathrm{Me}$. Furthermore, as previously observed, those complexes with chloride ligands produced a higher activity than the nitrate analogues. For biofilm-forming bacteria, however, we had observed that 2-H kept the potent activity but the ligand exchange to chloride in 3-H reduced the activity. This behaviour is replicated for the substituted counterparts: the 
nitrate-bearing complexes exhibited similar activity in planktonic and biofilm bacteria, while the chloride-ones are less efficient in biofilms. Again, the trend $\mathrm{H}<\mathrm{OMe}<\mathrm{Me}$ is generally observed for all the parameters tested.

\section{Discussion}

Metallodendrimers represent an attractive alternative to traditional antibiotics in the treatment of bacterial infections. Besides their promising bactericide and bacteriostatic activity, they offer valuable information about the impact of structural parameters on the therapeutic activity. The carbosilane metallodendrimers included in this study, together with those previously described [14], shape a useful library to analyse structureto-antimicrobial activity relationships of the metallodrug.

A competitive antimicrobial candidate must be produced through a simple and costefficient process. Even though dendrimers are known for their tedious synthetic process [18], carbosilane scaffolds offer important advantages: the low generation dendrimers show outstanding biological activity, thus reducing the length and costs of their preparation. For the present study, only first generation metallodendrimers-bearing four metal complexes on the periphery-were selected, as they had shown the most promising activity in former assays [14]. The family of cymene-Ru(II) metallodendrimers 1-R herein reported only requires a one-step synthetic route, under mild conditions and straightforward purification. This means a significant improvement from the 3-step route is required for cyclopentadienyl analogues. The R-substituted $\mathrm{Cu}$ (II) metallodendrimers had also proved technological advantages in the synthetic process, compared to the non-substituted analogues [16].

The coordination of the $\mathrm{Ru}(\mathrm{II})$ ions to the dendritic skeletons can be easily monitored through NMR spectroscopy (Table 1). We observed important shifts of the signals to higher frequency due to the effect of the electron-withdrawing metal. Furthermore, after the metal chelation, the cymene ring undergoes a loss of symmetry and generates a chiral molecule. This stereogenic centre induces a diastrophic effect around $-\mathrm{CH}_{2} \mathrm{~N}$ and the methylene groups adjacent to the imine appear as two sets of signals. This effect has been previously described for the metallodendrimer 1-H [17].

Most antibacterial dendrimers rely on an adequate cationic charge distribution and amphiphilicity to disrupt the negatively charged microbe membrane $[10,19,20]$. According to the conductivity and Z-potential results (Table 2), the metallodendrimers are positively charged and can disrupt bacterial membranes via electrostatic interactions or through exchange of the divalent metal ions which support the membrane. This non-specific mechanism reduces the possibilities to develop antibiotic resistance [11]. Among the $\mathrm{Ru}$ (II) complexes, the conductivity assays revealed that the cationic features decreased in the trend $\mathrm{H}>\mathrm{OMe}>\mathrm{Me}$. The substituents in 4-position to the pyridine nitrogen induce a different basicity of this atom: while the 4-methyl group induces a +I effect, the 4-methoxyl generates a predominant $+\mathrm{M}$ effect which delocalises the negative charge in the nitrogen atom. Both increase the basicity of the nitrogen atom towards Lewis acids such as $\mathrm{Ru}(\mathrm{II})$ and $\mathrm{Cu}(\mathrm{II})$, thus reducing the overall positive charge on the metal ion compared to the non-substituted $\mathbf{1 - H}, \mathbf{2}-\mathbf{H}$ and 3-H. This confirms the crucial role of the metal complex in the antibacterial activity and the impact of modifying the type of metal or ligands in the complex. Furthermore, the Ru-cymene family 1-R showed a good colloidal stability according to the Z-potential measurements, duplicating the values of the Ru-cyclopentadienyl derivative $\mathbf{4}-\mathbf{H}$ and the $\mathrm{Cu}$ metallodendrimers $\mathbf{2}-\mathrm{H}$ and $\mathbf{3}-\mathbf{H}$, with incipient instability [21]. The charge and colloidal stability of the metallodrug will also affect the antibacterial activity.

The antibacterial effect of the R-substituted metallodendrimers was tested using $S$. aureus as an example of Gram-positive bacteria, measuring the bacteriostatic and bactericide properties in planktonic cells (MIC, MBC) and biofilm-forming bacteria (MBIC, MIC, MBC$\mathrm{B})$. The assays confirmed the impact of the structural parameters-nature of the metal 
ion, ligands on the metal complex and substituents on the iminopyridine ring-on the antimicrobial activity

$\mathrm{Ru}(\mathrm{II})$ carbosilane metallodendrimers had previously shown a potent antibacterial activity in planktonic cells (MIC $=4 \mathrm{mg} / \mathrm{L}$ ), which unfortunately decreased towards biofilmforming bacteria [14]. The new family $\mathbf{1 - R}$, with cymene ligands in the ruthenium ion, does not improve the excellent activity in planktonic $S$. aureus and appear as moderate antibacterial agents (Table 2). Surprisingly, and despite the higher Z-potential of the cymene-bearing 1-H compared to the Cp-bearing 4-H, it shows lower activity (MIC $=16 \mathrm{mg} / \mathrm{L}$ ). The hydrophobicity and stability provided by the $\mathrm{Cp}$-ring together with the water-solubility and $\mathrm{pH}-$-responsiveness from the PTA ligand seem relevant for the antibacterial effect. A negative influence of the iminopyridine substituent is observed, decreasing the activity with the trend $\mathrm{H}>\mathrm{OMe}>\mathrm{Me}$, in agreement with the loss of positive charge observed through conductivity assays. Nevertheless, the presence of the ring substituent might be meaningful towards biofilms: the metallodendrimer 1-Me slightly improves the bacteriostatic and bactericide effect of ruthenium counterparts against biofilms. S. aureus biofilm formation occurs through diverse adherence mechanisms, based on polysaccharides, protein/eDNA, fibrin or amyloid proteins [22]. The increased lipophilicity $(+\pi)$ in 1-Me due to the methyl group may be responsible for the improvement in the preventive effect against biofilms, avoiding the adsorption of macromolecules to the surfaces and thus the formation of the extracellular polymeric matrix. Similarly, the increased hydrophobicity on cotton fabric after the deposition of $\mathrm{Cu}(\mathrm{II})$ poly(propylene imine) metallodendrimers prevented the formation of B. cereus and P. aeruginosa biofilms [23]. Both PPI and iminopyridine carbosilane dendrimers exhibit metal-chelating moieties in their scaffolds. The metal chelation reduces the polarity of the $\mathrm{M}$ (II) ion, increases the delocalisation of electrons over the chelate ring and increases the overall lipophilicity, favouring the penetration into the lipid cell membrane and overall improving the antibacterial effect. This highlights the importance of correctly balancing the charge and lipophilicity of the metallodrug.

$\mathrm{Cu}(\mathrm{II})$ carbosilane metallodendrimers had already shown potent activity in both planktonic S. aureus (MIC $=2-4 \mathrm{mg} / \mathrm{L}$ ) and biofilms (MBIC $=4-8 \mathrm{mg} / \mathrm{L}$ ) [14]. As data on Table 3 indicates, the presence of ring substituents increased the MIC values in the trend $\mathrm{H}$ $<\mathrm{OMe}<\mathrm{Me}$ and again confirmed the negative effect on the antibacterial activity. This trend is generally observed for all the parameters tested. Regarding the metal ligands, chloride produced a higher activity than nitrate in planktonic cells, but slightly lost the activity in biofilms. This behaviour had also been observed for the non-substituted counterparts 2-H and 3-H [14]. Unfortunately, no substituent/counterion pairs were detected which clearly improved the antibacterial action. This crossed influence of the substituent/counterion substantially increased the antitumor activity of 3-Me and 2-OMe due to a remarkable production of reactive oxygen species (ROS) in U937 tumour cells, while barely affecting healthy PBMCs [16]. This confirms the different mechanism of action to produce the antitumor and antimicrobial effects. For the antimicrobial activity, it could be interesting to explore the effect of alternative ring substituents such as $\mathrm{F}, \mathrm{Cl}$ or $\mathrm{NO}_{2}$, with $+\pi$ and $+\sigma$ properties [24], which may increase the overall lipophilicity and charge on the metallodrug.

We herein demonstrated that carbosilane metallodendrimers are a promising tool in the fight against Gram-positive bacteria, which cause important nosocomial infections in hospital facilities [2]. The presence of a thick peptidoglycan layer in these bacteria hampers the effective treatment and other dendrimers, such as PAMAM, reported difficulties to disrupt the crosslinked peptidoglycan layer [25]. Other metallodendrimers reported in the literature also showed antimicrobial effect towards planktonic S. aureus [13]. For example, a G2 aromatic polyamide dendrimer decorated with $6 \mathrm{Pd}(\mathrm{II})$ ions exhibited a moderate $\mathrm{MIC}=82 \mathrm{mg} / \mathrm{L}$, but comparable to the antibiotic streptomycin (MIC= $80 \mathrm{mg} / \mathrm{L}$ ) [26]. All carbosilane metallodendrimers described are far more effective, with MIC values ranging from 2 to $64 \mathrm{mg} / \mathrm{L}$. This confirms the potential of our nanomaterials as an alternative to traditional antibiotics. In another example, a G1 propyletherimine dendrimer decorated with $6 \mathrm{Ag}(\mathrm{I})$ carboxylate moieties showed MIC $=41.7 \mathrm{mg} / \mathrm{L}$ for $S$. aureus and $26.0 \mathrm{mg} / \mathrm{L}$ for 
methicillin-resistant S. aureus (MRSA) [27]. In this work, the authors demonstrated a direct relation between the number of $\mathrm{Ag}(\mathrm{I})$ ions and the antibacterial activity. Conversely, we have extensively demonstrated that first-generation carbosilane metallodendrimers are the most promising candidates and the G2 counterparts, which duplicate the number of metal ions, do not proportionally improve the activity [14,17]. The hydrophilic/hydrophobic balance in these metallodendrimers is crucial, and the overall antimicrobial activity is dictated not only by the metal, but also by the nature of the dendritic scaffold.

It is worth mentioning that none of the other metallodendrimers reported in the literature evaluated the effect towards biofilm-forming $S$. aureus, even though it is responsible for most human infections where $S$. aureus is involved. As we have proved, substantially different results may be obtained with the same metallodrug against planktonic and biofilm bacteria. For example, the Ru-cymene metallodendrimer 1-Me exhibited the lowest positive charge and antibacterial activity in planktonic cells among the $\mathrm{Ru}(\mathrm{II})$ complexes; however, it presented a promising preventive activity against biofilms $(\mathrm{MBIC}=16 \mathrm{mg} / \mathrm{L}$ and $\mathrm{MBC}-\mathrm{B}=64 \mathrm{mg} / \mathrm{L}$ ). This reveals the need for a thorough antibacterial study, covering both planktonic and biofilm-forming bacteria, and the importance of fine-tuning the compound structure in order to maximise the efficiency to the resistant biofilms. The aim is finding a potent biocide activity towards both modes of growth, such as that exerted by the $\mathrm{Cu}$-nitrate metallodendrimer 2-H $(\mathrm{MIC}=\mathrm{MBIC}=4 \mathrm{mg} / \mathrm{L})$ [14]. The higher cationic charge and lower membrane stabilisation of 2-H [15] may explain the potent biocide activity. Further studies are required to evaluate the capacity of these metallodendrimers to disrupt the formation of already formed biofilms.

The complete study on carbosilane metallodendrimers revealed that these metallodrugs merged different mechanisms of action to attain the overall antibacterial effect. The cationic charge and the lipophilicity of the molecule [16], together with underlying mechanisms from the metal ions, such as the production of reactive oxygen species, are responsible for the overall antibacterial effect [28]. These must be adequately balanced for a correct activity in biofilms.

\section{Materials and Methods}

\subsection{Metallodendrimers}

Solvents were purified from appropriate drying agents. Chemicals were purchased from commercial sources and used as received. Elemental analyses were performed on a LECO CHNS-932. NMR spectra were recorded on a Varian Unity VXR-300 Hz and 500 Hz instruments. Chemical shifts are given in ppm. ${ }^{1} \mathrm{H}$ and ${ }^{13} \mathrm{C}$ resonances were measured relative to internal deuterated solvents peaks. $\left\{{ }^{1} \mathrm{H}-{ }^{13} \mathrm{C}\right\}-\mathrm{HSQC}-2 \mathrm{D}-\mathrm{NMR}$ experiments were carried out to support the assignment of the signals.

4.1.1. Synthesis and Characterisation of R-Substituted Iminopyridine $\mathrm{Ru}(\mathrm{II})$ Metallodendrimers

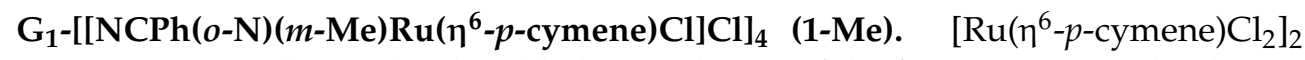
(35.0 mg, $0.0572 \mathrm{mmol}$ ) was slowly added to a solution of the first-generation dendrimer $\mathrm{G}_{1}-[\mathrm{NCPh}(o-\mathrm{N})(m-\mathrm{Me})]_{4}(30.7 \mathrm{mg}, 0.0286 \mathrm{mmol})$ in dry ethanol. The solution was stirred overnight at room temperature. Subsequently, the solvent was evaporated and the metallodendrimer 1-Me isolated as brown solid $(60.1 \mathrm{mg}, 92 \%)$.

${ }^{1} \mathrm{H}-\mathrm{NMR}\left(\mathrm{CD}_{3} \mathrm{OD}\right): \delta(\mathrm{ppm})=0.03\left(\mathrm{~s}, 24 \mathrm{H},-\left(\mathrm{CH}_{3}\right)_{2} \mathrm{Si}\right) ; 0.64\left(\mathrm{~m}, 24 \mathrm{H},-\mathrm{SiCH}_{2}\right) ; 1.03 \& 1.17$ $\left(2 \mathrm{~d}, 24 \mathrm{H},\left(\mathrm{CH}_{3}\right)_{2} \mathrm{CH}^{\mathrm{cym}}\right) ; 1.39$ (br m, 8H, $\left.-\mathrm{SiCH}_{2} \mathrm{CH}_{2} \mathrm{CH}_{2} \mathrm{Si}-\right) ; 1.94$ \& $2.04(2 \mathrm{~m}, 8 \mathrm{H}$, $\left.-\mathrm{CH}_{2} \mathrm{CH}_{2} \mathrm{~N}\right) ; 2.28\left(\mathrm{~s}, 12 \mathrm{H},-\mathrm{CH}_{3}{ }^{\mathrm{cym}}\right) ; 2.61\left(\mathrm{~s}, 12 \mathrm{H}, \mathrm{CH}_{3}{ }^{\mathrm{Pyr}}\right) ; 2.68\left(\mathrm{~m}, 4 \mathrm{H},-\left(\mathrm{CH}_{3}\right)_{2} \mathrm{CH}^{\mathrm{cym}}\right)$; $4.24 \& 4.68\left(2 \mathrm{~m}, 8 \mathrm{H},-\mathrm{CH}_{2} \mathrm{~N}\right) ; 5.83-5.79\left(\mathrm{~m}, 8 \mathrm{H}, \mathrm{Ar}^{\mathrm{cym}}\right) ; 6.05\left(\mathrm{~m}, 4 \mathrm{H}, \mathrm{Ar}^{\mathrm{cym}}\right) ; 6.17(\mathrm{~m}, 4 \mathrm{H}$, $\left.\mathrm{Ar}^{\mathrm{cym}}\right) ; 7.64$ (br s, 4H, Arpyr); 8.00 (s, 4H, Arpyr); 8.62 (s, 4H, -CH $\left.{ }^{\text {imine }}\right)$; 9.30 (s, 4H, Ar ${ }^{\text {pyr }}$ ); ${ }^{13} \mathrm{C}\left\{{ }^{1} \mathrm{H}\right\} \mathrm{NMR}\left(\mathrm{CD}_{3} \mathrm{OD}\right): \delta(\mathrm{ppm})=-3.0\left(-\left(\mathrm{CH}_{3}\right)_{2} \mathrm{Si}\right) ; 13.7\left(-\mathrm{SiCH}_{2} \mathrm{CH}_{2} \mathrm{CH}_{2} \mathrm{Si}\right) ; 18.6,19.1$, $19.8\left(-\mathrm{SiCH}_{2}\right) ; 21.1\left(-\mathrm{CH}_{3}{ }^{\mathrm{cym}} \&-\mathrm{CH}_{3}{ }^{\mathrm{pyr}}\right) ; 21.9,23.0\left(-\left(\mathrm{CH}_{3}\right)_{2} \mathrm{CH}^{\mathrm{cym}}\right) ; 25.8\left(-\mathrm{SiCH}_{2} \mathrm{CH}_{2} \mathrm{CH}_{2} \mathrm{~N}\right)$; $32.4\left(-\left(\mathrm{CH}_{3}\right)_{2} \mathrm{CH}^{\mathrm{cym}}\right) ; 71.5\left(-\mathrm{CH}_{2} \mathrm{~N}\right) ; 85.5,86.2,86.8,88.7\left(-\mathrm{CH}^{\mathrm{cym}}\right) ; 104.2,106.6\left(C^{\mathrm{cym}}\right) ; 130.3$, 
$130.6\left(C^{\text {pyr }}\right) ; 154.0,155.8,156.2\left(\mathrm{CH}^{\mathrm{pyr}}\right) ; 168.4\left(\mathrm{CH}^{\text {imine }}\right)$. Elemental Analysis (\%): Calc. For $\mathrm{C}_{100} \mathrm{H}_{156} \mathrm{Cl}_{8} \mathrm{~N}_{8} \mathrm{Ru}_{4} \mathrm{Si}_{5}$ (2298.70): C, 52.25; H, 6.84; N, 4.87; Found: C, 52.63; H, 7.24; N, 4.79. $\mathrm{G}_{1}$-[[NCPh$(o-\mathrm{N})(m-\mathrm{OMe}) \mathrm{Ru}\left(\eta^{6}-p\right.$-cymene $\left.\left.) \mathrm{Cl}\right] \mathrm{Cl}\right]_{4}$ (1-OMe). $\left[\mathrm{Ru}\left(\eta^{6}-p \text {-cymene }\right) \mathrm{Cl}_{2}\right]_{2}$ $(36.5 \mathrm{mg}, 0.0596 \mathrm{mmol})$ was slowly added to a solution of the first-generation dendrimer $\mathrm{G}_{1}-[\mathrm{NCPh}(o-\mathrm{N})(m-\mathrm{OMe})]_{4}(33.9 \mathrm{mg}, 0.0298 \mathrm{mmol})$ in dry ethanol. The solution was stirred overnight at room temperature. Subsequently, the solvent was evaporated and the metallodendrimer 1-OMe isolated as brown solid $(67.2 \mathrm{mg}, 96 \%)$.

${ }^{1} \mathrm{H}-\mathrm{NMR}\left(\mathrm{CD}_{3} \mathrm{OD}\right): \delta(\mathrm{ppm})=0.04\left(\mathrm{~s}, 24 \mathrm{H},-\left(\mathrm{CH}_{3}\right)_{2} \mathrm{Si}\right) ; 0.62\left(\mathrm{~m}, 24 \mathrm{H},-\mathrm{SiCH}_{2}\right) ; 1.05 \& 1.19$ $\left(2 \mathrm{~d}, 24 \mathrm{H},\left(\mathrm{CH}_{3}\right)_{2} \mathrm{CH}^{\mathrm{cym}}\right) ; 1.39$ (br m, 8H, $\left.-\mathrm{SiCH}_{2} \mathrm{CH}_{2} \mathrm{CH}_{2} \mathrm{Si}-\right) ; 1.93$ \& $2.04(2 \mathrm{~m}, 8 \mathrm{H}$, $\left.-\mathrm{CH}_{2} \mathrm{CH}_{2} \mathrm{~N}\right) ; 2.27$ (s, 12H, $\left.-\mathrm{CH}_{3}{ }^{\mathrm{cym}}\right) ; 2.69\left(\mathrm{~m}, 4 \mathrm{H},-\left(\mathrm{CH}_{3}\right)_{2} \mathrm{CH}^{\mathrm{cym}}\right) ; 4.05$ (s, 12H, $\left.\mathrm{OCH}_{3}{ }^{\mathrm{Pyr}}\right)$; $4.24 \& 4.67\left(2 \mathrm{~m}, 8 \mathrm{H},-\mathrm{CH}_{2} \mathrm{~N}\right) ; 5.77-5.81\left(2 \mathrm{~s}, 8 \mathrm{H}, \mathrm{Ar}^{\mathrm{cym}}\right) ; 6.02\left(\mathrm{~s}, 4 \mathrm{H}, \mathrm{Ar}{ }^{\mathrm{cym}}\right) ; 6.15(\mathrm{~s}, 4 \mathrm{H}$, $\left.\mathrm{Ar}^{\mathrm{cym}}\right)$ ) 7.34 (br s, 4H, Arpyr); 7.75 (s, 4H, Arpyr); 8.59 (s, 4H, -CH $\left.{ }^{\text {imine }}\right) ; 9.22$ (s, 4H, Arpyr); ${ }^{13} \mathrm{C}\left\{{ }^{1} \mathrm{H}\right\} \mathrm{NMR}\left(\mathrm{CD}_{3} \mathrm{OD}\right): \delta(\mathrm{ppm})=-2.9\left(-\left(\mathrm{CH}_{3}\right)_{2} \mathrm{Si}\right) ; 13.7\left(-\mathrm{SiCH}_{2} \mathrm{CH}_{2} \mathrm{CH}_{2} \mathrm{Si}\right) ; 18.6,19.1$, $19.8\left(-\mathrm{SiCH}_{2}\right) ; 21.1\left(-\mathrm{CH}_{3}{ }^{\mathrm{cym}}\right) ; 21.9$, $23.0\left(-\left(\mathrm{CH}_{3}\right)_{2} \mathrm{CH}^{\mathrm{cym}}\right) ; 25.8\left(-\mathrm{SiCH}_{2} \mathrm{CH}_{2} \mathrm{CH}_{2} \mathrm{~N}\right) ; 32.4$ $\left(-\left(\mathrm{CH}_{3}\right)_{2} \mathrm{CH}^{\text {cym }}\right) ; 57.6\left(\mathrm{OCH}_{3}\right) ; 71.4\left(-\mathrm{CH}_{2} \mathrm{~N}\right) ; 85.2,85.9,86.4,88.4\left(-\mathrm{CH}^{\text {cym }}\right) ; 103.8,106.3$ $\left(C^{\text {cym }}\right) ; 115.2,116.6\left(C^{\text {pyr }}\right) ; 157.4,157.5,168.5\left(\mathrm{CH}^{\mathrm{pyr}}\right) ; 169.7\left(\mathrm{CH}^{\text {imine }}\right)$. Elemental Anal. (\%): Calc. For $\mathrm{C}_{100} \mathrm{H}_{156} \mathrm{Cl}_{8} \mathrm{~N}_{8} \mathrm{O}_{4} \mathrm{Ru}_{4} \mathrm{Si}_{5}$ (2362.70): C, 50.84; H, 6.66; N, 4.74; Found: C, 51.17; H, $6.86 ; \mathrm{N}, 4.70$.

\subsubsection{Preparation of Metallodendrimers Samples}

Serial dilutions of the different biocides were prepared in sterile distilled water for ruthenium complexes 1-R and copper complexes with nitrate ligands $\mathbf{2}-\mathbf{R}$ and due to their good solubility, and in DMSO:water (1:99 at the highest concentration) for chloride copper complexes 3-R. The tested concentrations ranged from $0.0312 \mathrm{mg} / \mathrm{L}$ to $1024 \mathrm{mg} / \mathrm{L}$. The effect of DMSO at the different concentrations was evaluated in an independent study, ruling out any possible toxicity for antibacterial assays.

\subsection{Zeta Potential}

Zeta potential was measured using a Zetasizer Nano ZS instrument (Malvern Instruments, Malvern, UK)Five measurements in automatic mode with a range between 10 and 100 cycles of each sample were made. Compounds were measured in distilled water at a concentration of $30 \mu \mathrm{M}$. The data were analysed using Malvern software.

\subsection{Conductivity}

Conductivity was measured using an Orion 3 Star instrument (Thermo Scientific, Waltham, MA, United States) and a conductivity cell ref. 013005MD. Compounds were measured in Milli-Q water at a concentration of $850 \mathrm{mg} / \mathrm{L}$. As control samples, Milli-Q water $(<1 \mu \mathrm{S} / \mathrm{cm})$ and $\mathrm{KCl} 0.001 \mathrm{M}($ Scharlau, $147 \mu \mathrm{S} / \mathrm{cm})$ were employed.

\subsection{Bacterial Strains}

For this work, a strain of the Gram-positive Staphylococcus aureus (CECT 240) was employed, which was provided by the Spanish Type Culture Collection (CECT) in lyophilised form.

\subsection{In Vitro Antibacterial Activity Tests Against Planktonic Cells}

The assay was based on the ISO 20776-1:2006 protocol. First, bacteria were grown in a Petri dish with PCA culture medium for $24 \mathrm{~h}$ at $37^{\circ} \mathrm{C}$. After inoculation, bacteria were incubated with biocides at each of the sixteen concentrations $(0.0312$ to $1024 \mathrm{mg} / \mathrm{L})$, as well as with controls in sterile 96-well plates. The different concentrations of biocide were evaluated, as well as different controls to rule out any contamination or additional effects that could affect the correct reading of the plate (inoculum-sample without biocide; biocide-sample without inoculum; and culture medium-sample without inoculum and biocide) by triplicate. The plates were incubated for $24 \mathrm{~h}$ at $37{ }^{\circ} \mathrm{C}$. The plates were analysed using an Ultra Microplate reader (BIO-TEK Instruments, model ELx808, Winooski, 
Vermont, United States), using a wavelength of $630 \mathrm{~nm}$, at $\mathrm{t}=0 \mathrm{~h}$ and $\mathrm{t}=24 \mathrm{~h}$. The results were collected to obtain the minimum inhibitory concentration (MIC) of the biocide. Subsequently, $5 \mu \mathrm{L}$ of one of the repetitions of each biocide concentration and of the controls were deposited on a petri dish containing solid PCA medium. This test was performed in duplicate and incubated for $24 \mathrm{~h}$ to obtain the minimum bactericidal concentration (MBC) values. For the tests of antibacterial activity using 96-well plates, TSB (BD, ref. 211825) was used as culture medium. For the growth of bacteria in petri dish, Plate Account Agar (PCA) (Scharlau, ref. 01-161) was used as the culture medium.

\subsection{In Vitro Antibacterial Activity Tests to Prevent S. aureus Biofilm Formation}

The assay was based on the ISO 20776-1:2006 protocol. Bacteria were cultured by the streaking method in a PCA petri dish at $37^{\circ} \mathrm{C}$ for $24 \mathrm{~h}$ and then some colonies were taken and added to a tube containing Bacto Tryptic Soy Broth (BD, ref. 211825) until 0.5 units of McFarland scale were obtained. The tube was incubated at $37^{\circ} \mathrm{C}$ for $20 \mathrm{~h}$ to obtain the pre-inoculum. Afterwards, a dilution of 1:100 was made with the same medium (inoculum solution). An aliquot of $200 \mu \mathrm{L}$ of inoculum solution was mixed with $50 \mu \mathrm{L}$ of each of the 16 concentrations of the biocides and the controls in sterile 96-well plates and incubated at $28^{\circ} \mathrm{C}$ for $10 \mathrm{~h}$. The different concentrations of biocide were evaluated by triplicate and controls of inoculum, biocide and culture medium, were tested as well. Biofilm formation was measured as follows: first, the total absorbance of each well was measured using an Ultra Microplate reader (BIO-TEK Instruments, model ELx808, Winooski, Vermont, United States) at $630 \mathrm{~nm}$. After that, the supernatant (planktonic cells) was transferred to new 96-well plates and the absorbance was measured again, to determine the minimum inhibitory concentration (MIC). In the first 96-well plate, the remaining biofilms were stained with $1 \%$ violet crystal in water for $15 \mathrm{~min}$. After removing the excess dye with PBS (phosphate buffered saline, $10 \mathrm{mM}$, three gentle washing cycles), the plate was dried and $200 \mu \mathrm{L}$ of acetic acid (33\% water solution) was added to remove the dye inside the cells. The acetic acid solution was extracted from the well and deposited on another new 96-well plate in order to measure the absorbance of each well and determine the minimum biofilm formation inhibitory concentration (MBIC). In all cases, a $630 \mathrm{~nm}$ wavelength was used. The minimum bactericidal concentration for biofilms formation (MBC-B) was obtained using $5 \mu \mathrm{L}$ of one of the replicates of each biocide concentration and controls for inoculating a petri dish with PCA medium. The plate was incubated for $24 \mathrm{~h}$ at $37^{\circ} \mathrm{C}$, and the assay was performed in duplicate.

\section{Conclusions}

Nanotechnology can be key for the prevention and treatment of bacteria biofilms. Carbosilane metallodendrimers merge the structural perfection and multivalency of the dendritic scaffold with exclusive biocide mechanisms generated by the metal complexes. A thorough structural design of these metallodendrimers can generate promising alternatives to traditional antibiotics. The dendrimer generation, the nature of the metal ion and its ligands, as well as the substituents on the chelating moieties are critical parameters to finetune the antibacterial activity not only against planktonic cells, but also against the resistant biofilms. We herein demonstrated (1) the need for a simple synthetic process, to reach a competitive antimicrobial candidate; and (2) the importance of adequately balancing the charge and the lipophilicity of the metallodrug to efficiently prevent biofilm formation. Carbosilane metallodendrimers present a brilliant future ahead with many possibilities to further improve and modulate their antimicrobial activity through structural design.

Supplementary Materials: The following are available online at https: / www.mdpi.com/article / 10.3390/antibiotics10050589/s1, Figure S1: ${ }^{1} \mathrm{H}-\mathrm{NMR}$ and ${ }^{13} \mathrm{C}-\mathrm{NMR}$ of metallodendrimer 1-Me; Figure S2: ${ }^{1} \mathrm{H}-\mathrm{NMR}$ and ${ }^{13} \mathrm{C}-\mathrm{NMR}$ of metallodendrimer 1-OMe.

Author Contributions: Methodology, S.G.-G.; investigation, N.S.d.O. and C.L.; writing-original draft preparation, S.G.-G., C.L. and J.L.C.-P.; writing-review and editing, F.J.d.l.M.; visualization, 
J.L.C.-P.; supervision, J.S.; project administration, S.G.-G.; funding acquisition, F.J.d.1.M. and J.L.C.-P. All authors have read and agreed to the published version of the manuscript.

Funding: This research was funded by grants from MINECO (CTQ2017-86224-P); Comunidad de Madrid (Consortiums IMMUNOTHERCAN-CM B2017/BMD-3733 and NANODENDMED-II B2017/BMD-3703; Research Talent Attraction Program 2017-T2/IND-5243) and Junta de Comunidades de Castilla-la Mancha (project SBPLY/17/180501/000358). S.G.-G. acknowledges the funding support from the Beatriz Galindo grant BG20/00231 (Spanish Ministry of Universities) and the project CM/BG/2021-001 "SALUDEN" funded by Comunidad de Madrid and University of Alcalá in the course of action "Research funds for Beatriz Galindo grants program". CIBER-BBN is an initiative funded by the VI National R\&D\&I Plan 2008-2011, Iniciativa Ingenio 2010, Consolider Program, CIBER Actions and financed by the Instituto de Salud Carlos III with assistance from the European Regional Development Fund. N.S.d.O. wishes to thank JCCM for a predoctoral fellowship.

Conflicts of Interest: The authors declare no conflict of interest.

\section{References}

1. Harris, L.G.; Foster, S.J.; Richards, R.G. An introduction to Staphylococcus aureus, and techniques for identifying and quantifying $S$. aureus adhesins in relation to adhesion to biomaterials: Review. Eur. Cell. Mater. 2002, 4, 39-60. [CrossRef] [PubMed]

2. Di Ruscio, F.; Guzzetta, G.; Bjørnholt, J.V.; Leegaard, T.M.; Moen, A.E.F.; Merler, S.; Freiesleben de Blasio, B. Quantifying the transmission dynamics of MRSA in the community and healthcare settings in a low-prevalence country. Proc. Natl. Acad. Sci. USA 2019, 116, 14599-14605. [CrossRef]

3. Paharik, A.E.; Horswill, A.R. The Staphylococcal biofilm: Adhesins, regulation, and host response. Microbiol. Spectr. 2016, 4, 1-27. [CrossRef]

4. Berlanga, M.; Guerrero, R. Living together in biofilms: The microbial cell factory and its biotechnological implications. Microb. Cell. Fact. 2016, 15, 165. [CrossRef] [PubMed]

5. Majumdar, S.; Pal, S. Bacterial intelligence: Imitation games, time-sharing, and long-range quantum coherence. J. Cell. Commun Signal. 2017, 11, 281-284. [CrossRef] [PubMed]

6. Costerton, J.W.; Stewart, P.S.; Greenberg, E.P. Bacterial biofilms: A common cause of persistent infections. Science 1999, 284, 1318-1322. [CrossRef]

7. Sharma, D.; Misba, L.; Khan, A.U. Antibiotics versus biofilm: An emerging battleground in microbial communities. Antimicrob. Resist. Infect. Control 2019, 8, 76. [CrossRef]

8. Perazzi, B.; Camacho, M.; Bombicino, K.; Flores, Z.; Vay, C.; Famiglietti, A. Staphylococcus aureus: New and old antimicrobial agents. Rev. Argent. Microbiol. 2010, 42, 199-202.

9. Liu, Y.; Shi, L.; Su, L.; van der Mei, H.C.; Jutte, P.C.; Ren, Y.; Busscher, H.J. Nanotechnology-based antimicrobials and delivery systems for biofilm-infection control. Chem. Soc. Rev. 2019, 48, 428-446. [CrossRef]

10. Ortega, M.Á.; Guzmán Merino, A.; Fraile-Martínez, O.; Recio-Ruiz, J.; Pekarek, L.; Guijarro, L.G.; García-Honduvilla, N.; ÁlvarezMon, M.; Buján, J.; García-Gallego, S. Dendrimers and dendritic materials: From laboratory to medical practice in infectious diseases. Pharmaceutics 2020, 12, 874. [CrossRef]

11. Zarena, A.S.; Shubha, G. Dendrimer a new dimension in targeting biofilms. Mini-Rev. Med. Chem. 2013, 13, 1448-1461. [CrossRef] [PubMed]

12. Claudel, M.; Schwarte, J.V.; Fromm, K.M. New antimicrobial strategies based on metal complexes. Chemistry 2020, 2, 849-899. [CrossRef]

13. Sanz del Olmo, N.; Carloni, R.; Ortega, P.; García-Gallego, S.; de la Mata, F.J. Metallodendrimers as a promising tool in the biomedical field: An overview. Chapter One. In Advances in Organometallic Chemistry; Pérez, P.J., Ed.; Academic Press: Cambridge, MA, USA, 2020; Volume 74, pp. 1-52.

14. Llamazares, C.; Sanz del Olmo, N.; Ortega, P.; Gómez, R.; Soliveri, J.; de la Mata, F.J.; García-Gallego, S.; Copa-Patiño, J.L. Antibacterial effect of carbosilane metallodendrimers in planktonic cells of Gram-positive and Gram-negative bacteria and Staphylococcus aureus biofilm. Biomolecules 2019, 9, 405. [CrossRef] [PubMed]

15. Sanz del Olmo, N.; Carloni, R.; Bajo, A.M.; Ortega, P.; Fattori, A.; Gómez, R.; Ottaviani, M.F.; García-Gallego, S.; Cangiotti, M.; de la Mata, F.J. Insight into the antitumor activity of carbosilane $\mathrm{Cu}(\mathrm{II})$-Metallodendrimers through their interaction with biological membrane models. Nanoscale 2019, 11, 13330-13342. [CrossRef] [PubMed]

16. Carloni, R.; Sanz del Olmo, N.; Canonico, B.; Montanari, M.; Ciacci, C.; Ambrosi, G.; de la Mata, F.J.; Ottaviani, M.F.; GarcíaGallego, S. Elaborated study of $\mathrm{Cu}(\mathrm{II})$ carbosilane metallodendrimers bearing substituted iminopyridine moieties as antitumor agents. Eur. J. Med. Chem. 2021, 215, 113292. [CrossRef]

17. Maroto-Díaz, M.; Elie, B.T.; Gómez-Sal, P.; Pérez-Serrano, J.; Gómez, R.; Contel, M.; de la Mata, F.J. Synthesis and anticancer activity of carbosilane metallodendrimers based on arene ruthenium(II) complexes. Dalton. Trans. 2016, 45, 7049-7066. [CrossRef]

18. Dendrimer Chemistry: Synthetic Approaches Towards Complex Architectures; Malkoch, M.; García-Gallego, S. (Eds.) Royal Society of Chemistry: Cambridge, UK, 2020; p. 293. [CrossRef] 
19. García-Gallego, S.; Franci, G.; Falanga, A.; Gómez, R.; Folliero, V.; Galdiero, S.; De la Mata, F.J.; Galdiero, M. Function oriented molecular design: Dendrimers as novel antimicrobials. Molecules 2017, 22, 1581. [CrossRef]

20. Heredero-Bermejo, I.; Copa-Patiño, J.L.; Soliveri, J.; García-Gallego, S.; Rasines, B.; Gómez, R.; de la Mata, F.J.; Pérez-Serrano, $\mathrm{J}$. In vitro evaluation of the effectiveness of new water-stable cationic carbosilane dendrimers against Acanthamoeba castellanii UAH-T17c3 trophozoites. Parasitol. Res. 2013, 112, 961-969. [CrossRef]

21. Kumar, A.; Dixit, C.K. 3-Methods for characterization of nanoparticles. In Advances in Nanomedicine for the Delivery of Therapeutic Nucleic Acids; Nimesh, S., Chandra, R., Gupta, N., Eds.; Woodhead Publishing: Cambridge, UK, 2017; pp. 43-58. [CrossRef]

22. Zapotoczna, M.; O'Neill, E.; O'Gara, J.P. Untangling the diverse and redundant mechanisms of Staphylococcus aureus biofilm formation. PLoS Pathog. 2016, 12, e1005671. [CrossRef]

23. Bosch, P.; Staneva, D.; Vasileva-Tonkova, E.; Grozdanov, P.; Nikolova, I.; Kukeva, R.; Stoyanova, R.; Grabchev, I. New poly(propylene imine) dendrimer modified with acridine and its $\mathrm{Cu}(\mathrm{II})$ complex: Synthesis, characterization and antimicrobial activity. Materials 2019, 12, 3020. [CrossRef] [PubMed]

24. Kapoor, Y.; Kumar, K. Quantitative structure activity relationship in drug design: An overview. SF J. Pharm. Anal. Chem. 2019, 2, 1017.

25. Wang, L.; Erasquin, U.J.; Zhao, M.; Ren, L.; Zhang, M.Y.; Cheng, G.J.; Wang, Y.; Cai, C. Stability, antimicrobial activity, and cytotoxicity of poly(amidoamine) dendrimers on titanium substrates. ACS Appl. Mater. Interfaces 2011, 3, 2885-2894. [CrossRef] [PubMed]

26. Ahamad, T.; Mapolie, S.F.; Alshehri, S.M. Synthesis and characterization of polyamide metallodendrimers and their anti-bacterial and anti-tumor activities. Med. Chem. Res. 2012, 21, 2023-2031. [CrossRef]

27. Suleman, N.; Kalhapure, R.S.; Mocktar, C.; Rambharose, S.; Singh, M.; Govender, T. Silver salts of carboxylic acid terminated generation 1 poly (propyl ether imine) (PETIM) dendron and dendrimers as antimicrobial agents against S. aureus and MRSA. RSC Adv. 2015, 5, 34967-34978. [CrossRef]

28. Fuentes-Paniagua, E.; Sánchez-Nieves, J.; Hernández-Ros, J.M.; Fernández-Ezequiel, A.; Soliveri, J.; Copa-Patiño, J.L.; Gómez, R.; de la Mata, F.J. Structure-activity relationship study of cationic carbosilane dendritic systems as antibacterial agents. RSC Adv. 2016, 6, 7022-7033. [CrossRef] 